\title{
SUMBER DAYA TERUMBU KARANG PULAU PENATA BESAR, LEMUKUTAN DAN PULAU KABUNG PERAIRAN KALIMANTAN BARAT
}

\author{
Isa Nagib Edrus*), Yudi Siswantoro."), dan Imam Suprihanto **')
}

\begin{abstract}
ABSTRAK
Penelitian dilakukan pada bulan Juni 2004 bertujuan untuk mengetahui keanekaragaman jenis, distribusi dan persen tutupan karang serta faktor-faktor yang mungkin mengancam kerusakan lingkungan hidup di terumbu karang. Metode yang digunakan adalah Line Intercept Transect dan Observasi Langsung di lapangan pada 4 stasiun penelitian. Hasil penelitian menunjukkan bahwa keanekaragaman marga karang berkisar antara 13 sampai 16 genus. Persentase tutupan karang batu pada 4 stasiun penelitian masingmasing adalah $65,9 \%, 65,37 \%, 57,80 \%$, dan $78,9 \%$. Hal ini menunjukkan kondisi kesehatan karang yang baik dan sangat baik. Sebaran koloni karang mencapai kedalaman 7 meter. Faktor pembatas distribusi dan pertumbuhan karang ini adalah kekeruhan air yang cukup tinggi yang disebabkan oleh sedimen dari daratan.
\end{abstract}

\section{ABSTRACT: Coral reef resources of Penata Besar, Lemukutan, and Kabung Island in the coastal waters of west Kalimantan. By: Isa Nagib Edrus, Yudi Siswantoro, and Imam Suprihanto}

A study conducted in June 2004 aims to identify diversity, distribution, and percent covers of coral reefs and to identify some coral-survival threatening factors. Methods used were Line Intercept Transect (LIT) and filed observation on the four-study sites. The result shows that coral diversity ranged from 13 to 16 genus. Percentages of coral covers at the four-study sites were $65.9 \%, 65.37 \%, 57.80 \%$, and $78.9 \%$, respectivelly. These indicated good and excellent healths of the coral reefs. Coral colonnies expanded up to the 7-meter depth of coral growing posible areas. The high water turbidity due to upland sedimentation was a limitting factor for coral growth and its distribution.

Keywords: $\quad$ coral reefs, diversity, distribution, west Kalimantan

\section{PENDAHULUAN}

Laut Indonesia terdiri atas teritorial seluas \pm 4 juta $\mathrm{km}^{2}$, pulau sebanyak 17.508 , dan pantai terpanjang kedua di dunia $( \pm 81.000 \mathrm{~km})$ setelah Kanada. Sumber daya alam hayati dan non hayati yang terkandung didalamnya sangat kaya. Nilai estetika lingkungan yang dimilikinya juga sangat tinggi (Anonimous, 2002).

Distribusi sumber daya terumbu karang dari barat ke timur pada kepulauan Indonesia telah menjadi kekayaan atau asset negara bagi pertumbuhan ekonomi dimasa mendatang. Menurut Steffen (2004), data terakhir menunjukkan bahwa wilayah terumbu karang yang terdapat di Indonesia mencakup 14.542 $\mathrm{km}^{2}$ paparan karang (fringing reefs), $50.223 \mathrm{~km}^{2}$ karang pelindung (barrier reefs), $19.540 \mathrm{~km}^{2}$ karang atol, dan $1.402 \mathrm{~km}^{2}$ karang saaru (oceanic bank reefs). Kelestarian sumber daya terumbu karang ini menjadi tanggung jawab nasional dan secara global juga telah diklaim sebagai tanggung jawab internasional.

Berbagai program pembangunan wilayah pesisir dan laut telah dikembangkan untuk pengelolaan sumber daya yang berkelanjutan. Melimpahnya kekayaan sumber daya alam wilayah pesisir dan laut menjadi faktor pendorong bagi pelaksanaan perencanaan, pengelolaan, dan pemanfaatannya secara bijaksana. Kelemahan dalam pengelolaan sumber daya tersebut adalah bahwa Indonesia belum memiliki pedoman yang memadai untuk penataan ruang wilayah yang mengintegrasikan antara pedalaman, pesisir laut, dan pulau-pulau kecil (Anonimous, 2002).

Dampak negatif aktivitas pembangunan di daratan Kalimantan yang begitu besar atas perairan pantai merupakan contoh kelemahan pola perencanaan pembangunan selama ini. Perencanaan tersebut masih berorientasi pada paradigma kontinental dan bukan paradigma kepulauan abrasi pantai yang besar $(4,67 \mathrm{~km})$, penyusutan hutan mangrove (rata-rata 17.000 ha per tahun), serta tingkat sedimentasi yang tinggi merupakan indikator yang signifikan atas kasus kerusakan lingkungan hidup di daratan dan pesisir (Pontianak Post, 2004). Semua dampak buruk ini secara kumulatif dan perlahan sangat berdampak terhadap ekosistem yang potensial di perairan pantai dan pulau-pulau sekitar, seperti lamun dan terumbu karang.

\footnotetext{
.. Staf Peneliti pada Balai Pengkajian Teknologi Pertanian, Maluku

*) Staf Peneliti pada Pusat Survey Sumber Daya Alam Laut, BAKOSURTANAL
} 
Dalam kebutuhan evaluasi dan monitoring dampak pembangunan selama ini di Kalimantan Barat dibutuhkan data dan informasi yang beragam, diantaranya adalah inventarisasi data dan informasi terumbu karang setempat. Penelitian ini menjadi penting karena adanya kegiatan pembangunan di daratan yang secara perlahan menyebabkan degradasi sumber daya laut, sementara pada saat yang sama terjadi kekosongan data. Indikator terpilih yang cocok untuk kepentingan evaluasi dan monitoring tersebut adalah meliputi keanekaragaman, distribusi spasial, dan persen tutupan karang, serta faktor-faktor yang berpengaruh terhadap pertumbuhan karang.

Tujuan penelitian ini adalah untuk mengetahui keanekaragaman jenis, distribusi, dan persen tutupan karang serta faktor-faktor yang merusak lingkungan hidup terumbu karang.

\section{BAHAN DAN METODE}

Kegiatan survei lapang dilaksanakan pada Juni 2004 di wilayah perairan karang Pulau-pulau Penata Besar, Lumukutan, dan Pulau Kabung, Kabupaten Bengkayang, Kalimantan Barat. Pulau tersebut terletak diantara lintang koordinat geografi $00^{\circ} 40^{\prime} 00^{\prime \prime}$ $00^{\circ} 50^{\prime} 00^{\prime \prime}$ Lintang Selatan dan $108^{\circ} 40^{\prime} 00^{\prime \prime}-108^{\circ} 50^{\prime}$ 00" Bujur Timur (Gambar 1).

Metode yang digunakan dalam penelitian ini adalah Pengamatan Langsung (on the spot) dan Line Intercept Transect (LIT) (English et. al., 1994). Pengamatan langsung pada lingkungan dimaksudkan untuk membuat catatan atau mendokumentasikan fenomena alam dan kegiatan manusia. Terutama menyangkut kejadian-kejadian signifikan yang mungkin dapat dihimpun dari masyarakat atau observasi langsung, seperti kejadian-kejadian alam

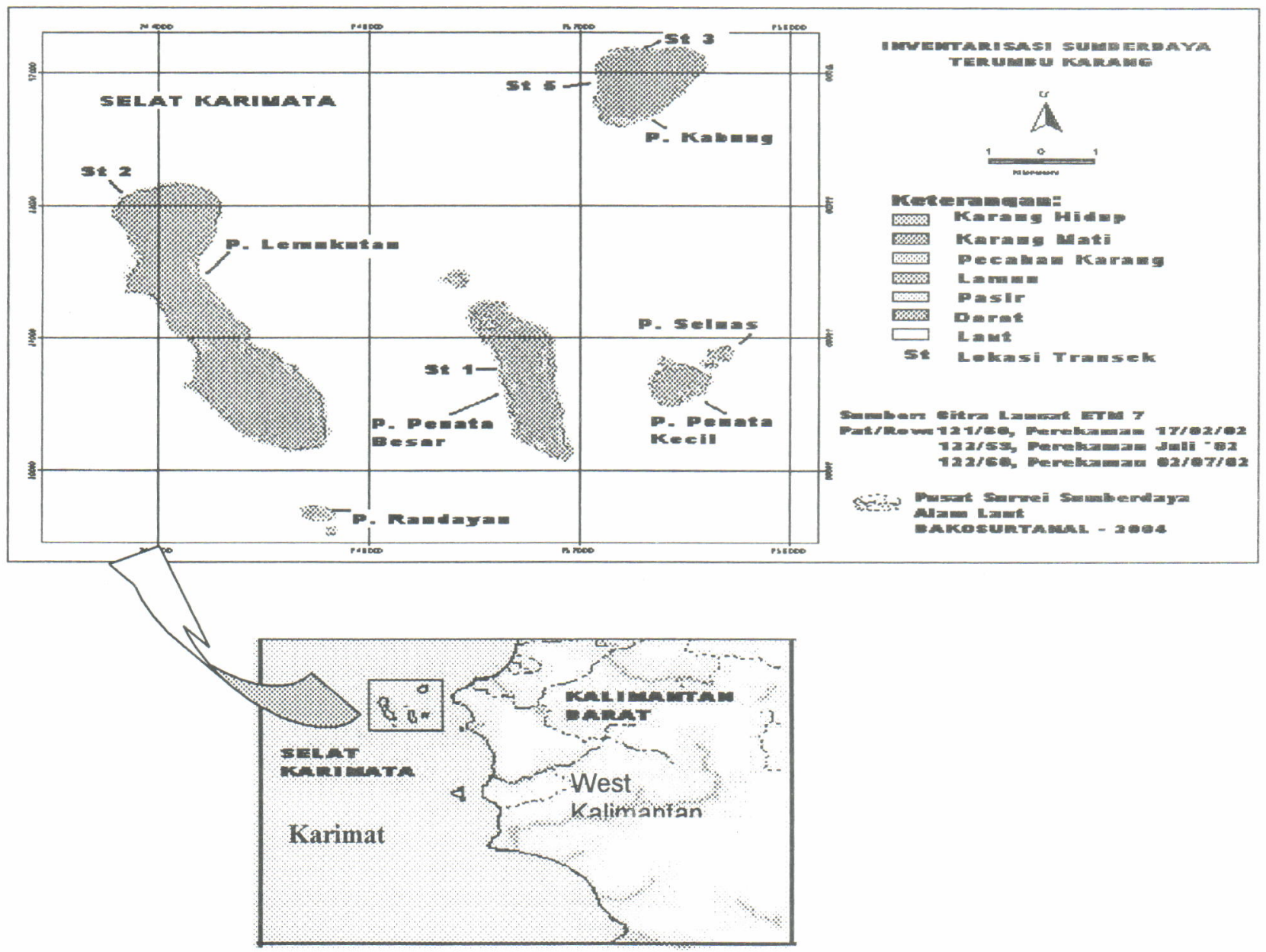

Gambar 1. Peta lokasi penelitian hasil interpretasi dari citra Landsat ETM-7 hasil perekaman tahun 2002 (Sumber Bakosurtanal, 2004).

Figure 1. The study site map derived from the 2002 recording of $7^{\text {th }}$ ETM Landsat Citra (Source: Bakosurtanal, 2004). 
(El Nino, banjir besar, dan badai topan), dan serangan bintang laut (Acanthaster plancii), atau kegiatankegiatan masyarakat yang menonjol (seperti pada sektor pertanian, perikanan, budi daya laut, transportasi, industri, dan lain-lain) dan dapat menjadi tanda-tanda dari adanya faktor alam dan manusia yang berpengaruh pada kondisi terumbu karang. Hasil dokumentasi ini kemudian diklasifikasikan ke dalam matrik yang dapat menggambarkan fenomena alam mana yang bersifat (faktor) negatif dan juga yang positif bagi keberadaan dan kelestarian terumbu karang. Jika kerusakan terumbu karang terjadi, hal ini dapat diprediksi sebagai akibat dari faktor-faktor tersebut, atau sebaliknya.

Metode LIT digunakan untuk mengidentifikasi persentasi tutupan karang batu dan kategori bentuk kehidupan bentik (Bentic Lifeform). Kategori ini menyediakan diskripsi morfologi komunitas karang. Setiap stasiun dipasang 1 LIT dengan posisi kedalaman berkisar antara 3 sampai 7 meter. Panjang LIT adalah 10 meter. Pengukuran dilakukan 3 kali ulangan, sehingga setiap stasiun mendapat porsi pengukuran sepanjang 30 meter. Setiap kategori lifeform (Tabel 2) dicatat pada data sheets oleh penyelam yang berenang sepanjang pita transek LIT (rol meter). Metode LIT memperkirakan tutupan dari objek atau kelompok sesuai kategorinya dalam suatu area tertentu dengan cara menghitung panjang fraksi (cm) objek yang dilewati oleh pita transek. Perhitungan fraksi tersebut dilakukan untuk menentukan persen tutupan benthic lifeform, yang kemudian dikenal sebagai "persen tutupan" (coral cover) (English et. al., 1994).

Tinjauan umum lokasi LIT dideskripsikan dalam tabel dan posisi geografis lokasi LIT didokumentasikan dengan GPS. Perairan pulau-pulau tersebut di mana keempat stasiun penelitian ditempatkan tidak terbebas dari pengaruh daratan, terutama terlihat dari tingginya kekeruhan air laut akibat sedimentasi. Tetapi pada perairan tersebut tidak ada laporan tentang penangkapan ikan dengan cara merusak, misalnya penggunaan racun dan bahan peledak. Pengelolaan sumber daya perikanan oleh masyarakat (community-based resource management) di wilayah ini lebih ditujukan untuk penggunaan daerah tangkapan ikan teri, di mana area bagan teri ke arah laut relatif dekat dengan area karang.

\section{Analisis Data Karang}

Analisis persen tutupan benthic lifeform tersebut menggunakan Lifeform Software Program berdasarkan standar UNEP yang berlaku untuk ASEAN-Australia (Rahmat \& Yosephine, 2001). Kondisi karang batu (hard coral) mengacu pada kriteria kesehatan karang yang diukur menurut kategori persentase tutupan karang seperti sangat baik (excellent) >75\%; baik (good) <75\%->50\%; sedang (Fair) $<50->25 \%$; dan buruk (poor) $<25 \%$ (Chou, 1998).

Tabel 1. Gambaran umum lokasi transek pada setiap stasiun

Table 1. The common description of transect sites

\begin{tabular}{|c|c|c|c|c|c|}
\hline Stasi it & $\begin{array}{l}\text { Postsi Geografis } \\
\text { (Geographical } \\
\text { Position of the } \\
\text { Transects) }\end{array}$ & $\begin{array}{l}\text { Dasar Perairan dan } . \\
\text { Persentasj Tutupan } \\
\text { percent Gover of corats) }\end{array}$ & $\begin{array}{l}\text { Jarak } \\
\text { Pandang } \\
\text { (Bodizontal } \\
\text { Visibility) }\end{array}$ & (water current) & $\begin{array}{l}\text { Nama Lokas) } \\
\text { (study sites) }\end{array}$ \\
\hline 1 & $\begin{array}{l}\text { S } 00^{\circ} 45^{\prime} 77,9^{\prime \prime} \\
\text { E } 108^{\circ} 45^{\prime} 54,3^{\prime \prime}\end{array}$ & $\begin{array}{l}\text { Reef slope, batuan } \\
\text { Vulkanik, pasir lumpur }\end{array}$ & $\begin{array}{l}\text { buruk } \\
(4 \mathrm{~m})\end{array}$ & Lemah & $\begin{array}{c}\text { P. Penata Besar } \\
\text { Berpenduduk, } \\
\text { Wilayah } \\
\text { Penangkapan ikan } \\
\text { teri }\end{array}$ \\
\hline 2 & $\begin{array}{l}500^{\circ} 4807,0 \\
\text { E } 108^{\circ} 41^{\prime} 56.0\end{array}$ & $\begin{array}{c}\text { Rer stope, batuan } \\
\text { Uulkanik pasir }\end{array}$ & $60 \mathrm{n}$ & - emat & $\begin{array}{l}\text { p Lenuuktan } \\
\text { pejpenduduk } \\
\text { penangkapan kan }\end{array}$ \\
\hline 3 & $\begin{array}{l}\text { S } 00^{\circ} 50^{\prime} 24,0^{\prime \prime} \\
\text { E } 108^{\circ} 47^{\prime} 04,0^{\prime \prime}\end{array}$ & $\begin{array}{l}\text { Reef slope, batuan } \\
\text { Vulkanik, pasir lumpur }\end{array}$ & $\begin{array}{l}\text { buruk } \\
(4 \mathrm{~m})\end{array}$ & Lemah & $\begin{array}{c}\text { P. Kabung } \\
\text { Berpenduduk, } \\
\text { Wilayah } \\
\text { Penangkapan ikan } \\
\text { teri }\end{array}$ \\
\hline 4 & $600^{\circ} 49 \cdot 76.7$ & rulkan sope, batuan & buruk & sedang & $\begin{array}{c}\text { perpenduduk } \\
\text { penangkapan kan }\end{array}$ \\
\hline
\end{tabular}


Tabel 2. Daftar lifeform dan kodenya masing-masing (dimodifikasi dari Dartnall \& Jones, 1986, dalam English et. al., 1994)

Table 2. The lifeform list and its respective codes (modified from Dartnall \& Jones, 1986, in English et. al., 1994)

\begin{tabular}{|c|c|c|c|}
\hline $\begin{array}{c}\text { Kategori } \\
\text { Categories }\end{array}$ & $\begin{array}{l}\text { Kode } \\
\text { Code }\end{array}$ & $\begin{array}{c}\text { Ketegori } \\
\text { Categories }\end{array}$ & $\begin{array}{l}\text { Kode } \\
\text { Code }\end{array}$ \\
\hline Karang keras (Hard Corals) & \multicolumn{2}{|r|}{ Ganggang (A/gae) } & \\
\hline Golongan Acropora (Acropora) & & - Macro Algae (MA) & MA \\
\hline - Acropora Branching (ACB) & ACB & - $\quad$ Turf Algae (TA) & TA \\
\hline - $\quad$ Acropora Encrusting (ACE) & ACE & - $\quad$ Coralline Algae (CA) & $\mathrm{CA}$ \\
\hline Acropora Submassive (ACS) & ACS & - $\quad$ Halimeda Algae (HA) & $\mathrm{HA}$ \\
\hline - $\quad$ Acropora Tabulate $(A C T)$ & $\mathrm{ACT}$ & - Algal Assemblage (AA) & AA \\
\hline \multirow{2}{*}{$\begin{array}{l}\text { Golongan bukan Acropora (Non- } \\
\text { Acropora) }\end{array}$} & & Fauna lain (Other Fauna) & \\
\hline & & - $\quad$ Soft Corals (SC) & SC \\
\hline - $\quad$ Coral Branching $(B C)$ & CB & Sponge (SP) & SP \\
\hline Coral Encrusting (CE) & $\mathrm{CE}$ & - Zoanthids (ZO) & 20 \\
\hline Coral Foliose (CF) & CF & - $\quad$ Others (OT) & OT \\
\hline Coral Massive (CM) & CM & & \\
\hline Coral Submassive (CS) & CS & Golongan bukan hayati (Abiotic) & \\
\hline Coral Musroom (CMR) & CMR & - Sand (S) & \\
\hline Coral Millepora (CME) & CME & - Rubble (R) & $\begin{array}{l}0 \\
0\end{array}$ \\
\hline Coral Heliopora (CHL) & $\mathrm{CHL}$ & - $\quad$ Silt $(\mathrm{SI})$ & $\begin{array}{l}R \\
\text { SI }\end{array}$ \\
\hline \multirow{2}{*}{ Karang mati (Dead Scleractinia) } & & - Water (WA) & WA \\
\hline & DC & - $\quad$ Rock (RCK) & RCK \\
\hline $\begin{array}{ll}- & \text { Dead Coral (DC) } \\
- & \text { Dead Coral with Algae (DCA) }\end{array}$ & $\mathrm{DCA}$ & & \\
\hline
\end{tabular}

\section{HASIL DAN BAHASAN}

\section{Kondisi Terumbu Karang}

Hasil analisis kondisi terumbu karang dengan program lifeform untuk masing-masing hasil pengukuran fauna karang pada LIT di setiap stasiun disajikan pada Tabel 3, 4, 5, dan 6. Tabel 3 menunjukkan bahwa kesehatan terumbu di Pulau Penata Besar digolongkan pada kondisi baik, yaitu menurut kriteria (Chou, 1998) yang sudah dijelaskan pada metodologi, di mana persen tutupan karang keras (hard corals) yang menjadi indikator dalam kriteria kesehatan tersebut ditemukan rata-rata sebesar $65,9 \%$. Tutupan karang keras tersebut didominasi oleh non-acropora (rata-rata 61\%), sedangkan kelompok acropora, yaitu jenis karang yang memiliki pori-pori pada permukaannya, kurang dapat tumbuh berkembang di wilayah ini, di mana tingkat kekeruhan dan sedimentasi yang tinggi. Ratarata area tutupan Acropora spp. hanya 4,9\%. Tabel 3 juga menunjukkan bahwa di wilayah transek Pulau Penata Besar tidak dijumpai adanya karang yang baru mati atau pemutihan karang (coral bleaching). Satusatunya indikator yang menunjukkan bahwa di area ini pernah terjadi kerusakan karang adalah besarnya area tutupan turf algae (rata-rata 18,4\%). Algae ini merupakan pioner yang selalu lebih cepat tumbuh pada permukaan-permukaan karang yang mati.
Fauna-fauna terumbu karang yang lain pada wilayah transek tersebut, yang mana merupakan komponen pembentuk keindahan terumbu karang adalah karang lunak (soft corals) dan spon (sponges). Area tutupannya masing-masing adalah rata-rata $12,63 \%$ dan $2,23 \%$. Sedangkan komponen abiotik, seperti pasir (sand), batuan (rock), pecahan karang (rubbles) tidak dijumpai sepanjang 3 kali ulangan transek. Ini menunjukkan bahwa wilayah karang di perairan Pulau Penata Besar memiliki sebaran spasial yang rapat dan tidak dijumpai adanya kasus pengrusakan karang.

Kondisi yang nyaris serupa dengan kondisi yang didiskripsikan di atas dijumpai pada stasiun 2 Pulau Lemukutan (Tabel 4), tetapi bentuk kehidupan bentik dari non-acropora pada Pulau Lemukutan lebih beragam.

Dalam hubungannya dengan asal-usu pertumbuhan karang, diasumsikan bahwa Pulau Kabung nampaknya memiliki sejarah sukses yang berbeda, hasil observasi lapangan pada stasiun 3 dan 4 di Pulau Kabung menunjukkan bahwa hampir sebagian besar karang keras di area ini merupakan generasi baru pertumbuhan karang (new recruitments) yang tumbuh di atas batu-batu vulkanis. Batuan vulkanis yang banyak terdapat di area tersebut memberikan substrat yang baik bagi 
Tabel 3. Rata-rata persen tutupan bentuk kehidupan bentik pada terumbu karang Pulau Penata Besar, Kalimantan Barat, menurut transek pada stasiun ke-1

Table 3. An average percentage of benthic lifeform cover in the coral reef area of Penata Besar Islands, West Kalimantan, by transects of the first study site

\begin{tabular}{|c|c|c|c|c|c|}
\hline \multirow{3}{*}{ (Lifeform Categories) } & \multirow{3}{*}{ Goder } & \multicolumn{4}{|c|}{ 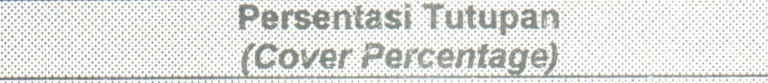 } \\
\hline & & \multicolumn{4}{|c|}{ Nomor Transek (Transect Number) } \\
\hline & & 1 & 2. & 3 & $\begin{array}{l}\text { Rata rata } \\
\text { (Mean) }\end{array}$ \\
\hline Total of Hard corals & & 4510 & 64,90 & 87,70 & 65,9 \\
\hline HARD CORALS (Acropores) & & 6.00 & , & 8.70 & 4.9 . \\
\hline Branching & $A C B$ & 6,00 & - & 2,50 & 2,8 \\
\hline Tabulate & ACT & - & - & 4,50 & 1,5 \\
\hline Encrusting & ACE & - & - & 1,70 & 0,6 \\
\hline Submassive & ACS & - & - & - & \\
\hline Digitate & $A C D$ & - & - & - & - \\
\hline HARD CORALS (Non-Acropores) & & 39.10 & 64,90 & 79,00 & 61,0 \\
\hline Branching & CB & - & - & 62,40 & 20,8 \\
\hline Massive & $\mathrm{CM}$ & 34,70 & 55,60 & 7,40 & 32,6 \\
\hline Encrusting & $\mathrm{CE}$ & 2,30 & 6,50 & 9,20 & 6,0 \\
\hline Submassive & CS & 2,10 & 2,00 & - & 1,36 \\
\hline Foliose & CF & - & - & - & \\
\hline Mushroom & CMR & - & 0,80 & - & 0,26 \\
\hline Millepora & CME & - & - & - & \\
\hline Heliopora & $\mathrm{CHL}$ & - & - & - & \\
\hline DEAD SCLERACTINIA & & 0 & 0 & 0 & 0 \\
\hline Dead Coral & DC & - & - & - & - \\
\hline (With algal Covering) & DCA & - & - & - & \\
\hline ALGAE & & 18,50 & 29,10 & 7,60 & 18,4 \\
\hline Macro & MA & & - & - & - \\
\hline Turf & TA & 18,50 & 29,10 & 7,60 & 18,4 \\
\hline Coralline & $\mathrm{CA}$ & - & - & - & - \\
\hline Halimeda & $\mathrm{HA}$ & - & - & - & - \\
\hline Algal Assemblage & AA & - & - & - & - \\
\hline OTHER FAUNA & & 34.90 & 6,00 & 4,70 & 15,2 \\
\hline Soft Coral & SC & 28,80 & 6,00 & 3,10 & 12,63 \\
\hline Sponge & SP & 6,10 & - & 0,60 & 2,23 \\
\hline Zoanthids & ZO & - & - & - & - \\
\hline Others & OT & - & - & 1,00 & 0,33 \\
\hline ABIOTIC & & 0 & 0 & 0 & 0 \\
\hline Sand & $\mathrm{s}$ & - & - & - & - \\
\hline Rubble & $\mathbf{R}$ & - & - & - & - \\
\hline Silt & SI & - & - & - & - \\
\hline Water & WA & - & - & - & - \\
\hline Rock & RCK & - & - & - & - \\
\hline
\end{tabular}

Sumber (Source): Hasil survei lapang Juni 2004

pertumbuhan karang keras, di mana memberikan peluang yang sama baik untuk kelompok acropora maupun non-acropora. Tabel 5 menunjukkan bahwa area tutupan dari kelompok Acropora spp. yang didominasi oleh bentukan meja (ACT-Acropora Tabulate) rata-rata sebesar $10,3 \%$, sedangkan untuk kelompok non-acropora sebesar $47,5 \%$. Dari dua komponen bentuk kehidupan bentik karang keras tersebut, persen tutupan karang menjadi rata-rata $57,8 \%$. Hal ini berarti bahwa terumbu karang pada stasiun 3 Pulau Kabung memiliki kondisi kesenatan yang "baik". Sementara komponen lain terumbu karang (other fauna) yang turut membentuk keindahan area bawah laut Pulau Kabung adalah karang lunak (soft cora/s) dengan area tutupan sebesar $10,84 \%$ dan spon (sponges) dengan area tutupan sebesar $3,73 \%$.

Tiga transek garis yang dipasang di stasiun 3 tidak semuanya melalui komponen biotik, tetapi $24,93 \%$ di 
Tabel 4. Rata-rata persen tutupan bentuk kehidupan bentik pada terumbu karang Pulau Lemukutan, Kalimantan Barat, menurut transek pada stasiun ke-2

Table 4. An average percentage of benthic lifeform cover in the coral reef area of Lemukutan Islands, West Kalimantan, by transects of the second study site

\begin{tabular}{|c|c|c|c|c|c|}
\hline \multirow{3}{*}{ (Lireform Categories) } & \multirow{3}{*}{ Kode } & \multicolumn{4}{|c|}{ 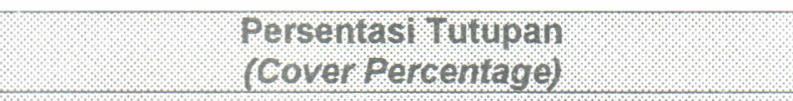 } \\
\hline & & \multicolumn{4}{|c|}{ Nomor Transek (Transect Number) } \\
\hline & & 1 & 2 & 3 & (Mata rata \\
\hline Total of Hard Corals & & 44,70 & 60.20 & 91,20 & 65.37 \\
\hline HARD CORALS (Acropores) & & 6.10 & 4,60 & 0. & 3,57 \\
\hline Branching & $A C B$ & 1,90 & 4,60 & - & 2,17 \\
\hline Tabulate & ACT & 4,20 & - & - & 1,40 \\
\hline Encrusting & ACE & - & - & - & - \\
\hline Subrnassive & ACS & - & - & - & - \\
\hline Digitate & $A C D$ & - & - & - & - \\
\hline HARD CORALS (Non-Acropores) & & 88,60 & 55,60 & 91,20 & 61,80 \\
\hline Branching & CB & 1,50 & 1,00 & - & 0,83 \\
\hline Massive & CM & 19,80 & 43,20 & 20,50 & 27,83 \\
\hline Encrusting & CE & - & - & & - \\
\hline Submassive & CS & 12,20 & 11,10 & 55,00 & 26,10 \\
\hline Foliose & CF & 0,30 & - & 10,50 & 3,60 \\
\hline Mushroom & CMR & 1,20 & 0,30 & 0,50 & 0,67 \\
\hline Millepora & CME & 3,60 & - & - & 1,2 \\
\hline Heliopora & $\mathrm{CHL}$ & - & - & 4,70 & 1,57 \\
\hline DEAD SCLERACTINIA & & 0 & 0 & 0 & 0 \\
\hline Dead Coral & DC & - & - & - & - \\
\hline (With algal Covering) & DCA & - & - & - & - \\
\hline ALGAE & & 15,70 & 32,40 & 4,30 & 17,47 \\
\hline Macro & MA & & - & - & - \\
\hline Turf & TA & 15,70 & 32,40 & 4,30 & 17,47 \\
\hline Coralline & $\mathrm{CA}$ & - & - & - & - \\
\hline Halimeda & HA & - & - & - & - \\
\hline Algal Assemblage & $A A$ & - & - & - & - \\
\hline OTHER FAUNA & & 39,60 & 7,40 & 4,50 & 17.17 \\
\hline Soft Coral & SC & 33,10 & 7,40 & 4,50 & 15,00 \\
\hline Sponge & SP & 6,50 & - & - & 2,17 \\
\hline Zoanthids & ZO & - & - & - & - \\
\hline Others & OT & - & - & - & - \\
\hline ABIOTIC & & 0 & 0 & 0 & 0 \\
\hline Sand & s & - & - & - & - \\
\hline Rubble & $\mathrm{R}$ & - & - & - & - \\
\hline Silt & SI & - & - & - & - \\
\hline Water & WA & - & - & - & - \\
\hline Rock & RCK & - & - & - & - \\
\hline
\end{tabular}

antaranya melalui komponen abiotik seperti pasir dan batu (Tabel 5). Ini berarti distribusi spasial karang pada Pulau Kabung tidak rapat atau dengan kata lain tidak semua substrat ditumbuni karang.

Kondisi yang nyaris serupa dengan kondisi di stasiun 3 tersebut di atas ditemukan pada stasiun 4 (Tabel 6), yaitu di sisi lain Pulau Kabung, namun kesehatan karang di stasiun 4 termasuk dalam kriteria "sangat baik" (excellent) dengan area tutupan karang keras sebesar rata-rata $78,9 \%$. Kondisi terumbu karang di stasiun 4 ini adalah yang terbaik dibanding area karang lainnya pada Pulau Penata Besar dan Pulau Lemukutan.

Gambar 2 berikut ini mengilustrasikan diagram cakram yang merupakan ringkasan dari kondisi karang pada masing-masing stasiun. Diagram cakram ini dapat digunakan sebagai bagian integral dari persentase data dan informasi spasial kondisi karang pada lay out peta. Diagram cakram ini menunjukkan bahwa semua area karang di masing-masing stasiun tergolong sehat atau termasuk kategori "baik" (stasiun 1, 2, dan 3) sampai "sangat baik" (stasiun 4). 
Tabel 5. Rata-rata persen tutupan bentuk kehidupan bentik pada terumbu karang Pulau Kabung, Kalimantan Barat, menurut transek pada stasiun ke-3

Table 5. An average percentage of benthic lifeform cover in the coral reef area of Kabung Islands, West Kalimantan, by transects of the third study site

\begin{tabular}{|c|c|c|c|c|c|}
\hline \multirow{3}{*}{ (Lifeform Categories) } & \multirow{3}{*}{$\begin{array}{l}\text { Kode } \\
\text { Code }\end{array}$} & \multicolumn{4}{|c|}{$\begin{array}{l}\text { Persentasi Tutupan } \\
\text { cover percentage) }\end{array}$} \\
\hline & & \multicolumn{4}{|c|}{ Nomor Transek (Transect Number). } \\
\hline & & , & 2. & 3. & $\begin{array}{l}\text { Rata rata } \\
\text { (Mear) }\end{array}$ \\
\hline Total or Hard Corals & & 55,30 & 60.50 & 57,60 & 67,80 \\
\hline HARD CORALS (Acropores) & & 410 & 14,40 & 12,40 & 10,30 \\
\hline Branching & $A C B$ & 4,10 & - & - & 1,37 \\
\hline Tabulate & ACT & - & 13,00 & 12,40 & 8,47 \\
\hline Encrusting & ACE & - & 1,40 & - & 0,46 \\
\hline Submassive & ACS & - & - & - & - \\
\hline Digitate & $A C D$ & - & - & - & - \\
\hline HARD CORALS (Non-Acropores) & & 51,20 & 46.10 & 45,20 & 47,50 \\
\hline Branching & $\mathrm{CB}$ & - & - & - & - \\
\hline Massive & $\mathrm{CM}$ & 34,60 & 30,50 & 23,30 & 29,47 \\
\hline Encrusting & CE & 13,20 & 9,10 & 4,30 & 8,87 \\
\hline Submassive & cs & 2,70 & 4,40 & 17,60 & 8,23 \\
\hline Foliose & CF & - & 2,10 & - & 0,70 \\
\hline Mushroom & CMR & - & - & - & - \\
\hline Millepora & CME & 0,70 & - & - & 0,23 \\
\hline Heliopora & $\mathrm{CHL}$ & - & - & - & - \\
\hline DEAD SCIERACTINIA & & 0. & 0 & 0. & 0 \\
\hline Dead Coral & DC & - & - & - & - \\
\hline (With algal Covering) & DCA & - & - & - & - \\
\hline ALGAE & & 6.10 & 2,00 & 0 & 27 \\
\hline Macro & MA & - & - & - & - \\
\hline Turf & TA & 6,10 & 2,00 & - & 2,7 \\
\hline Coralline & $C A$ & - & - & - & - \\
\hline Halimeda & $\mathrm{HA}$ & - & - & - & - \\
\hline Algal Assemblage & $A A$ & - & - & - & - \\
\hline OTHERFAUNA & & 20,50 & 17.40 & 5,80 & 14.57 \\
\hline Soft Coral & SC & 16,80 & 12,20 & 3,50 & 10,84 \\
\hline Sponge & $\mathrm{SP}$ & 3,70 & 5,20 & 2,30 & 3,73 \\
\hline Zoanthids & ZO & - & - & - & - \\
\hline Others & OT & - & - & - & - \\
\hline ABIOTIC & & 18,10 & 20,10 & 36,60 & 24.93 \\
\hline Sand & S & 1,20 & - & - & 0,40 \\
\hline Rubble & $\mathrm{R}$ & - & - & - & - \\
\hline Silt & SI & - & - & - & - \\
\hline Water & WA & - & - & - & - \\
\hline Rock & RCK & 16,90 & 20,10 & 36,60 & 24,53 \\
\hline
\end{tabular}

\section{Distribusi Tempat Tumbuh dan Faktor Pembatas}

Hasil temuan penelitian jelas mengindikasikan bahwa karang dan fauna lainnya yang berasosiasi di dalam terumbu dapat tumbuh dengan baik mulai dari kedalaman 3 sampai 7 meter, walaupun diketahui tingkat kekeruhan badan air cukup tinggi akibat pengaruh sedimentasi lumpur dari daratan Pulau Kalimantan. Apa yang menyebabkan terumbu karang tetap eksis di wilayah keruh ini adalah karena bantuan arus air yang kuat dan ombak yang cukup besar, di samping penetrasi sinar matahari masih cukup baik Gerakan air, termasuk ombak, adalah faktor penting yang menentukan zonasi karang, morfologi karang, dan distribusi kedalaman terumbu karang, ganggang, dan fauna karang yang lain (Wilkinson \& Evans, 1989). Kedua pergerakan massa air ini secara periodik mencuci permukaan karang yang ditutupi oleh sedimen. 
Tabel 6. Rata-rata persen tutupan bentuk kehidupan bentik pada terumbu karang Pulau Kabung, Kalimantan Barat, menurut transek pada stasiun ke-4

Table 6. An average percentage of benthic lifeform cover in the coral reef area of Kabung Islands, West Kalimantan, by transects of the fourth study site

\begin{tabular}{|c|c|c|c|c|c|}
\hline \multirow{3}{*}{ (Liferorm Carcgonles) } & \multirow{3}{*}{$\begin{array}{l}\text { Kode } \\
\text { Code }\end{array}$} & \multicolumn{4}{|c|}{$\begin{array}{l}\text { Persentasi Tutupan } \\
\text { (Cover Percentage) }\end{array}$} \\
\hline & & \multicolumn{4}{|c|}{ Nomor Transek (Tronsect Number). } \\
\hline & & 1 & 2 & 3 & $\begin{array}{l}\text { Rata-rata } \\
\text { Mean) }\end{array}$ \\
\hline Total of Hard Corals & & 71.90 & 72,6 & 92,2 & $\frac{78.9}{9}$ \\
\hline HARD CORALS (Acropores) & & 25,80 & 29,00 & 78,70 & 44.5 \\
\hline Branching & $A C B$ & 11,20 & 2,30 & 4,00 & 5,83 \\
\hline Tabulate & $\mathrm{ACT}$ & 14,60 & 26,70 & 73,9 & 38,4 \\
\hline Encrusting & ACE & - & & 0,80 & 0,27 \\
\hline Submassive & ACS & - & & - & - \\
\hline Digitate & $A C D$ & - & - & - & - \\
\hline HARD CORALS (Non-Acropores) & & 46,10 & 43,60 & 13,50 & 34,4 \\
\hline Branching & CB & - & & - & - \\
\hline Massive & $\mathrm{CM}$ & 29,10 & 24,10 & 6,20 & 19,80 \\
\hline Encrusting & $C E$ & 8,00 & 3,10 & 2,50 & 4,53 \\
\hline Submassive & CS & 9,00 & 2,30 & 2,50 & 4,60 \\
\hline Foliose & CF & & 14,10 & 2,30 & 5,47 \\
\hline Mushroom & CMR & & & & - \\
\hline Millepora & CME & & & & - \\
\hline Heliopora & $\mathrm{CHL}$ & - & & - & - \\
\hline DEAD SCLERACTINIA & & 0 & 3,80 & 0 & 1,27 \\
\hline Dead Coral & $D C$ & & & . & - \\
\hline (With algal Covering) & $D C A$ & - & 3,80 & & 1,27 \\
\hline ALGAE & & 3,80 & 3,30 & 2,30 & 3,13 \\
\hline Macro & MA & & & & - \\
\hline Turf & TA & 3,80 & 3,30 & 2,30 & 3,13 \\
\hline Coralline & $C A$ & - & & - & - \\
\hline Halimeda & $H A$ & & & - & - \\
\hline Algal Assemblage & $A A$ & - & - & - & - \\
\hline OTHER FAUNA & & 14,30 & 10,20 & 3,50 & 9,33 \\
\hline Soft Coral & SC & 14,00 & 10,20 & 3,50 & 9,23 \\
\hline Sponge & SP & 0,30 & & & 0,10 \\
\hline Zoanthids & 20 & & & - & - \\
\hline Others & OT & - & - & - & - \\
\hline ABIOTIC. & & 10,00 & 10,10 & 2,00 & 7,37 \\
\hline Sand & $S$ & 3,50 & 10,10 & 2,00 & 5,20 \\
\hline Rubble & $\mathrm{R}$ & - & - & - & - \\
\hline Silt & $S !$ & - & & . & - \\
\hline Water & WA & - & & - & - \\
\hline Rock & RCK & 6,50 & & - & 2,17 \\
\hline
\end{tabular}

Tetapi sedimentasi yang tinggi dapat saja tidak teratasi sehingga menjadi faktor pembatas fisik bagi kehidupan biota bentik. Gambar 3 menunjukkan adanya sisa-sisa debris lumpur yang menyelimuti badan karang. Sebagian debris memang tersapu, tetapi sebagian masih tertinggal pada saat arus melemah. Secara fisik debris yang berasal dari sedimen ini sangat mempengaruhi kehidupan karang.
Kondisi yang tidak menguntungkan (unfavorable) ini jelas membatasi pertumbuhan karang secara spasial. Karang hanya mungkin tumbuh dan berkembang pada rentang gradien persyaratan tumbuh yang dapat ditoleransi olehnya. Terumbu karang adalah unik di antara komunitas atau asosiasi makhluk hidup di laut yang di dalamnya organisme karang membangun aktivitas biologis secara 


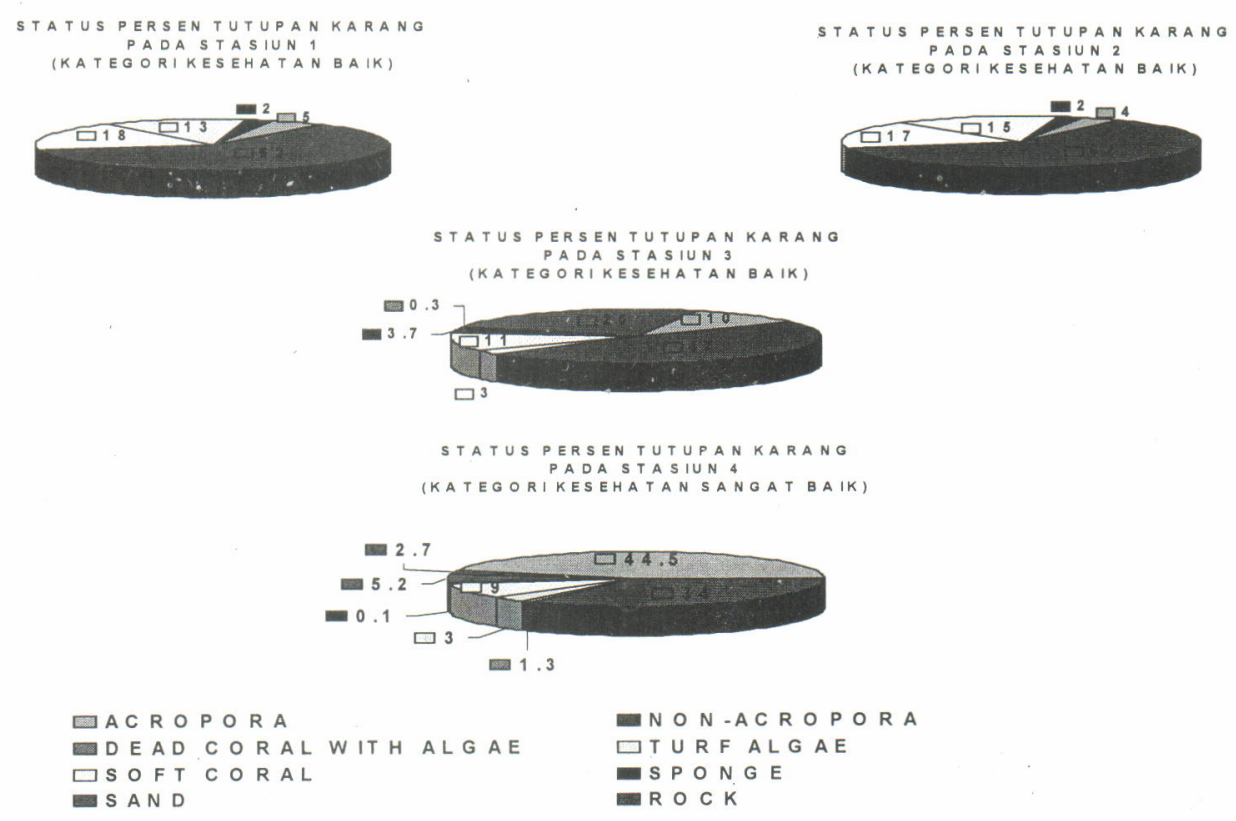

Gambar 2. Kondisi kesehatan karang pada masing-masing stasiun penelitian yang ditunjukkan oleh persen tutupan karang keras (Acropora dan non-acropora).

Figure 2. $\quad$ Percentage of hard coral covers (Acropora and non-acropora) showing the health status of respective study sites.

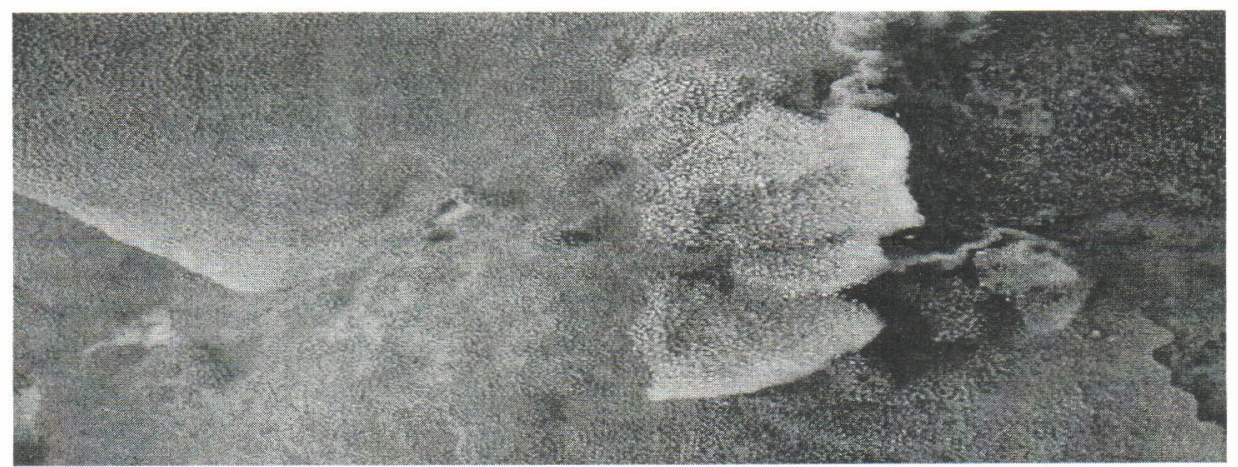

Gambar 3. Permukaan karang berbentuk folium yang ditutupi lumpur sedimen.

Figure 3. Overflowing debris covered the skin of coral folium.

menyeluruh. Terumbu karang pada dasarnya adalah deposit massive dari kalsium karbonat yang telah dihasilkan oleh organisme karang (dari filum Cnidaria, ordo Scleractinia) dengan mendapat tambahan terutama dari ganggang berkalsium (calcareous algae) dan biota-biota karang lain yang mensekresikan kalsium karbonat. Faktor-faktor lingkungan yang membatasi pertumbuhan karang sebenarnya adalah unsur-unsur dari karang yang menyokong pembentukan kerangka terumbu dan pondasi tumbuh yang cukup, seperti diilustrasikan pada Gambar 4 (White, 1987).

Komunitas karang terbatas keberadaannya pada perairan dangkal, karena ganggang simbiotik membutuhkan sinar matahari untuk fotosintesis. Kebutuhan dan adaptasi sinar dalam koral seperti untuk kepentingan memelihara laju maksimum dari pengkapuran dan fotosintesis dapat dipertahankan hingga di bawah kedalaman 20 meter dalam kondisi perairan bersih (Falkowski et. al., 1990).

Penetrasi cahaya matahari dalam badan air dapat dihambat oleh tingkat turbiditas, sehingga laju sidementasi yang tinggi dapat berpengaruh buruk pada koral dan karang, di antaranya adalah menurunnya kecepatan tumbuh dan menghambat pembentukan koloni-koloni baru (Brown \& Howard, 1985; Babcock \& Davies, 1991; Wilkinson \& Buddemeier, 1994). 


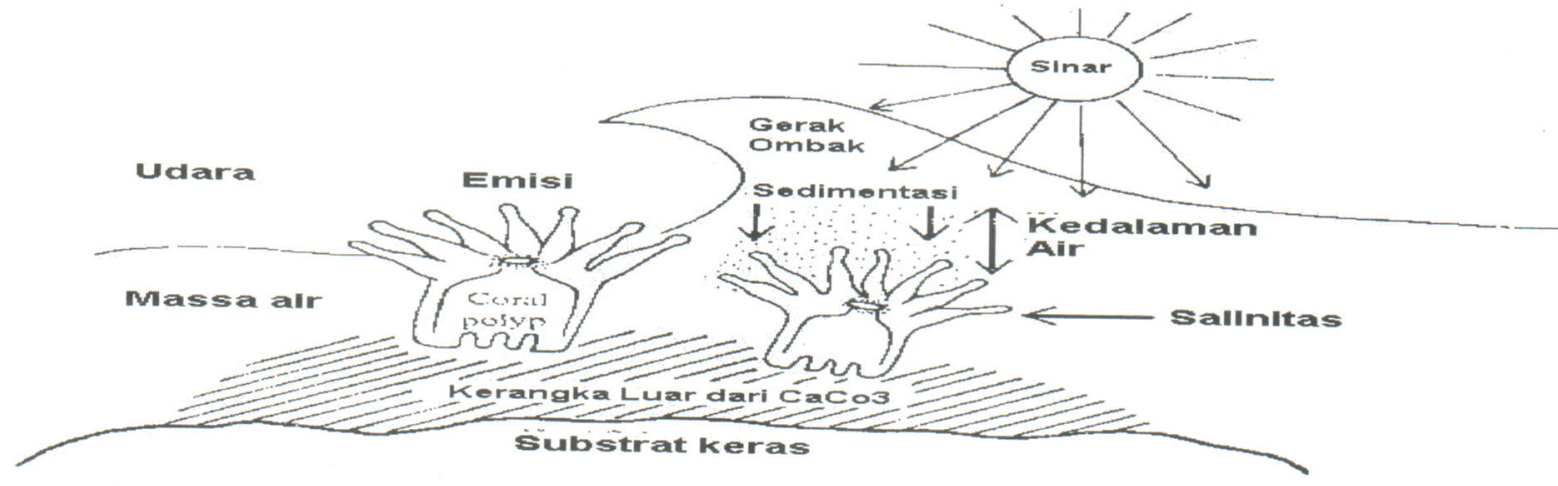

Gambar 4. Pembatas fisik pertumbuhan karang (polyp karang) (White, 1987).

Figure 4. Some physical constraints of growing reefs (coral polyps) (White, 1987).

Seperti diketahui bahwa karang dan organisme mikroskopik simbiosanya (Zooxanthella) membutuhkan sinar matahari untuk proses fotosintesa dalam kaitannya dengan memelihara ketersediaan makanan, walaupun karang juga mendapat sediaan nutrien dari daratan. Sedimentasi yang berlebihan secara fisik akan mempengaruhi polyp karang dan secara tidak langsung akan membatasi penetrasi sinar matahari. Dengan demikian, sebaran karang sangat dibatasi oleh kedalaman dan kecerahan massa air. Kecerahan yang diukur dengan piring secchi menunjukkan adanya tingkat kekeruhan yang cukup tinggi di area penelitian. Kecerahan tersebut bervariasi dari 3,5 meter sampai 6 meter. Oleh karena itu, sebaran karang di masing-masing pulau terbatas sampai kedalaman 7 meter ke arah laut. Penyelaman yang dilakukan lebih dalam dari 7 meter tidak menemukan lagi karang keras hidup, kecuali bongkahan batu karang mati, batuan vulkanik, dan organisme spon.

Hasil observasi pendahuluan dengan peralatan kamera sea hawk di sekitar pulau-pulau tersebut menunjukkan bahwa karang sudah tidak dijumpai lagi pada kedalaman sekitar 10 meter. Pada kedalaman ini dasar perairan ditutupi oleh pasir lumpur dan batuan (Gambar 5). Sedangkan Gambar 6 menunjukkan zonasi yang umum dari dasar perairan pantai yang dijumpai di area penelitian Pulau Penata Besar, Lemukutan, dan Pulau Kabung. Sedangkan bentuk pantai diperlihatkan oleh Gambar 7 di bawah ini.

\section{Jenis dan Komposisi Karang}

Marga (Genus) dan jenis (Species) karang yang dapat tumbuh di pulau-pulau tersebut, berdasarkan pada hasil sensus di area transek, disajikan pada Tabel 7. Pada perairan pulau-pulau yang lebih terbuka terhadap ombak besar, seperti pada Pulau Penata Besar, dan Lemukutan, terumbu karang didominasi oleh karang berbentuk massive (coral massive) atau berbentuk submassive. Contoh karang massive di antaranya adalah dari marga Diploastrea, Favites, Goniastrea, Lobophyllia, Platygyra, Porites, dan Oulophyllia.

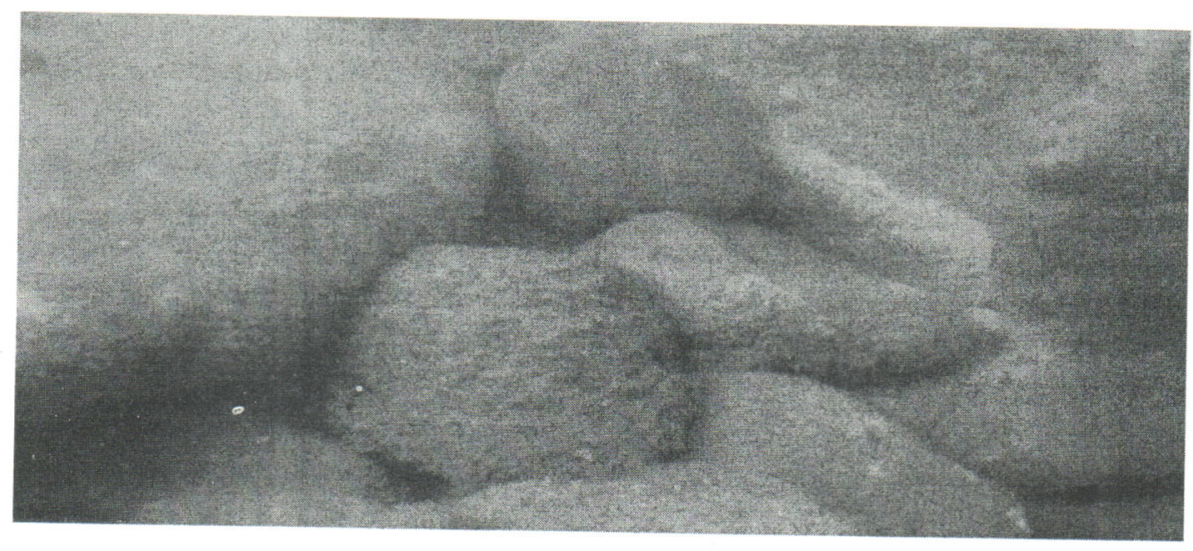

Gambar 5. Dasar perairan pantai pada kedalaman lebih dari 10 meter, sebagian ditutupi oleh batuan dan
lumpur.

Figure 5. The ten-meter bottom sea covered by sediment and rocks. 


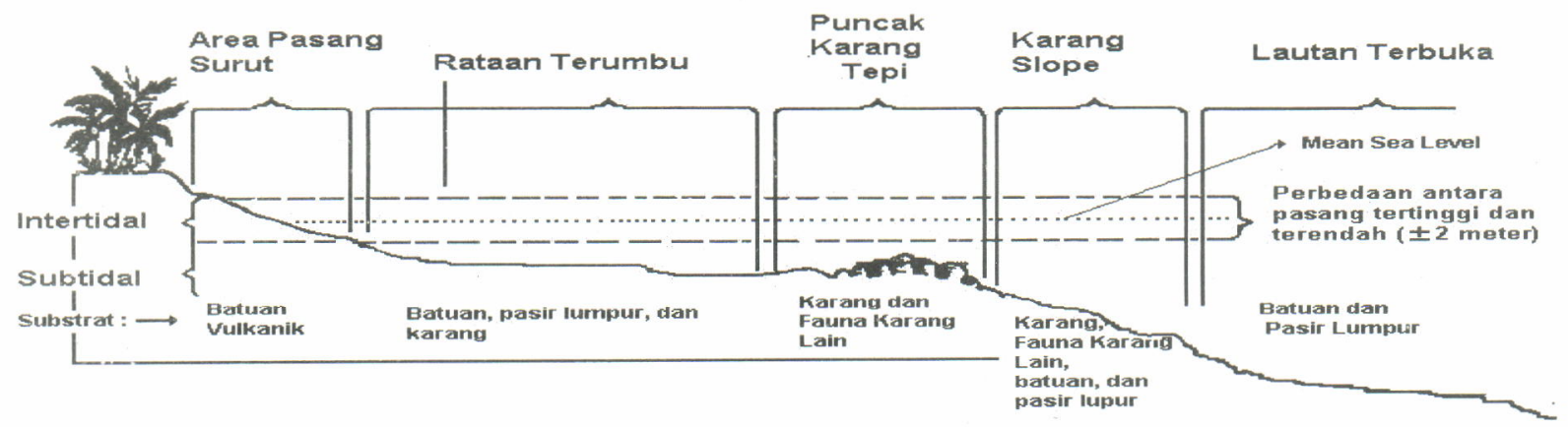

Gambar 6. Zonasi yang menggambarkan sebaran karang dan substrat perairan di lokasi penelitian. Figure 6. A cross section showing coral reef distribution and other subtrates in the study sites.
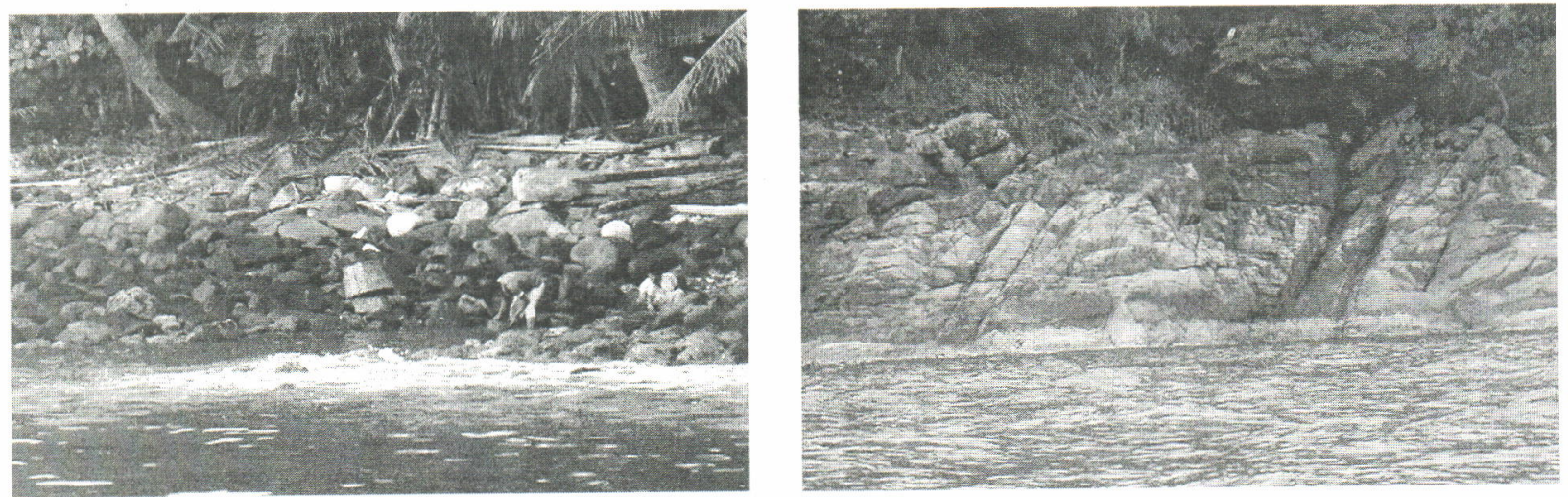

Gambar 7. Kondisi tepi pantai Pulau Kabung (kiri) dan Pulau Lemukutan (kanan).

Figure 7. Rocky shores of Kabung Island (left) and Lemukutan Island (right).

Contoh karang submassive di antaranya adalah Pocillopora, Merulina, Montipora, dan Porites. Semua marga tersebut adalah termasuk golongan nonacropora. Sedangkan pada perairan yang relatif terlindung dari pengaruh ombak besar, seperti Pulau Kabung, golongan karang berbentuk percabangan (acropora branching atau coral branching) atau berbentuk meja (acropora tabulate) dapat tumbuh berkembang dan bahkan mendominasi terumbu karang. Contohnya pada stasiun 3 dan 4. Karang bercabang (coral branching) dan karang meja (coral tabulate) ini yang ditemukan di area transek meliputi berbagai jenis dari marga Acropora. Jumlah marga di wilayah penelitian ini masih sedikit dibanding wilayah karang di perairan subur (Edrus. t.t.).

\section{Pengaruh Lingkungan}

Tabel 8 memberikan suatu ringkasan tentang faktor-faktor lingkungan apa saja yang mungkin berpengaruh terhadap terumbu karang di wilayah penelitian, baik pengaruh positif maupun negatif terhadap distribusi, kehidupan, pertumbuhan, dan keberlangsungan hidup organisme karang di lingkungan perairan karang. Beberapa aktivitas pembangunan, seperti penggundulan hutan dan lahan mangrove, pembukaan lahan budi daya udang, pertambangan emas liar, dan abrasi pantai dari
Sungai Duri sampai Singkawang $(4,67 \mathrm{~km})$ di wilayah Kalimantan Barat ternyata menimbulkan dampak negatif terhadap pesisir pantai. Terutama meningkatkan sedimentasi, di mana kekeruhan air sampai mencapai pulau-pulau yang ada di sekitarnya. Hal ini diperburuk pula oleh adanya sungai-sungai besar, hilangnya vegetasi mangrove dan lamun. Tetapi sebaliknya pelumpuran yang terjadi di wilayah tepi pantai daratan Kalimantan, seperti di wilayah Singkawang dan Sambas, ternyata membangun habitat untuk berbagai jenis udang. Karena aktivitas pertanian disekitarnya ternyata memberikan cukup nutrien bagi udang-udang tersebut.

Semula pengaruh aktivitas pertanian (terutama eutrifikasi pada massa air) dikhawatirkan menjadi penyebab blooming biota pemakan karang, seperti bintang laut Acanthaster plancii. Tetapi di area penelitian tidak dijumpai adanya biota tersebut. Oleh karena itu tidak tercatat adanya karang mati akibat serangan biota tersebut.

Selain di Pulau Karimata, tidak ada laporan tentang penggunaan bahan beracun dan peledak dalam penangkapan ikan di area penelitian. Oleh karena itu, tidak ditemukan adanya pecahan-pecahan karang (rubbles) pada area transek, di mana kondisi karang cukup baik dan berkembang tanpa gangguan. 
Tabel 7. Komposisi marga karang keras menurut jumlah frekuensi kemunculannya dalam area garis transek pada masing-masing stasiun Genera of coral composition by number of occurences identified on the line transect of respective study sites

\begin{tabular}{|c|c|c|c|c|}
\hline \multirow{2}{*}{$\begin{array}{c}\text { Marga/Jenis karang Keras } \\
\text { (Genus/Species of Hard Corals) }\end{array}$} & \multicolumn{4}{|c|}{ Lokasi transek (Transect Sites) } \\
\hline & St. 1 & St. 2 & St. 3 & St. 4 \\
\hline Acropora spp. & 5 & 3 & 7 & 25 \\
\hline Diploastrea heliopora & 1 & 3 & & \\
\hline Diploastrea spp. & 6 & & & \\
\hline Favia maxima & & 1 & & \\
\hline Favia sp. & 1 & 6 & 15 & 8 \\
\hline Favites spp. & 3 & 4 & 4 & 3 \\
\hline Fungia spp. & 2 & 5 & & \\
\hline Galaxea fascicularis & & 7 & & \\
\hline Galaxea sp. & & & 2 & 10 \\
\hline Goniastrea aspera & 2 & 2 & & \\
\hline Goniastrea retiformis & & 1 & & \\
\hline Goniastrea spp. & 8 & 4 & 18 & 14 \\
\hline Goniopora sp. & & & & 1 \\
\hline Heliopora sp. & & 1 & & \\
\hline Leptoria sp. & & & 1 & \\
\hline Lobophyllia spp. & 7 & & 2 & 4 \\
\hline Melliopora sp. & 1 & & 1 & \\
\hline Merulina spp. & 2 & 2 & & 2 \\
\hline Montipora sp. & 7 & & 4 & 1 \\
\hline Oulophyllia sp. & 1 & & & \\
\hline Pachyseris rugosa & & 1 & & \\
\hline Pachyseris spp. & & 4 & & \\
\hline Pavona sp. & & & 1 & 8 \\
\hline Platygyra lamellia & & 2 & & \\
\hline Platygyra sp. & 1 & & & \\
\hline Pocillopora spp. & 3 & 4 & 6 & 4 \\
\hline Porites lobata & 12 & 7 & 3 & 2 \\
\hline Porites spp. & 1 & 5 & 12 & 12 \\
\hline Symphyllia fascicularis & 1 & & & \\
\hline Symphyllia nobilis & & 2 & & \\
\hline Symphyllia sp. & & 10 & 2 & 1 \\
\hline Tridacna squamossa & 1 & & & \\
\hline Tubipora musica & & 3 & & 1 \\
\hline Jumlah Marga (Genus Number) & 16 & 16 & 13 & 15 \\
\hline Jumlah Frekuensi Kemunculan & & & & \\
\hline (Number of Occurance) & 65 & 77 & 78 & 96 \\
\hline
\end{tabular}

Pada perairan pantai pulau-pulau tersebut di atas tidak dijumpai adanya hutan mangrove dan padang lamun. Padahal kedua ekosistem ini memiliki peran penting dalam kaitannya dengan eksistensi terumbu karang. Terutama sebagai pendukung nutrien, penahan sedimen, dan mempengaruhi secara positif keanekaragaman ikan. Sedangkan pantai memiliki banyak batuan vulkanik yang dapat dijadikan bahan konstruksi bangunan. Secara tidak langsung hal ini menghindarkan orang untuk menambang karang.

Seluruh faktor positif ini dapat menjawab mengapa karang dapat tumbuh dengan baik pada beberapa pulau seperti Penata Besar, Lemukutan, dan Kabung. Sebaliknya karena faktor negatif tersebut di atas terjawab sudah mengapa terumbu karang tidak dijumpai pada perairan pantai yang lebih dalam. 
Tabel 8. Faktor-faktor lingkungan yang mungkin berpengaruh terhadap terumbu karang-kehidupan, pertumbuhan dan keberlangsungan hidup-baik pengaruh pcsitif maupun negatif

Table 8. Environmetal factors possibly influencing on life, growth, and survival of coral reefs-either positive or negative

\begin{tabular}{|c|c|c|}
\hline $\begin{array}{l}\text { raktor faktor yang : } \\
\text { (nntuencing Factors) }\end{array}$ & $\begin{array}{l}\text { Status Pengamin } \\
\text { Ternadap P eratran } \\
\text { (Impact on Reet : } \\
\text { Areas) }\end{array}$ & 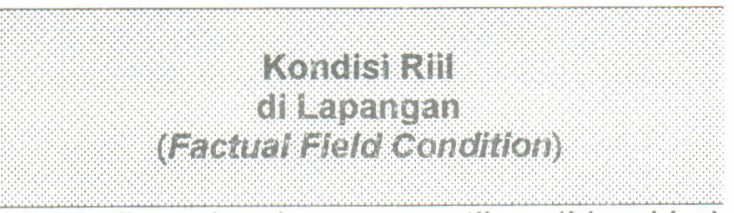 \\
\hline Suhu ekstrim (EL NINO) & new & $\begin{array}{l}\text { Tidak ditemukan kasus pemutihan (bleaching) } \\
\text { karang. }\end{array}$ \\
\hline Arus dan ombak & t: & $\begin{array}{l}\text { Cukup kuat unuk mencegah pengendapan } \\
\text { sedimen pada pernukaan karang. }\end{array}$ \\
\hline Sedimen & - & $\begin{array}{l}\text { Turbiditas sangat tinggi, menyebabkan } \\
\text { kekeruhan \& kematian karang. }\end{array}$ \\
\hline Penetrasi cahaya (Kecerahan) & t & $\begin{array}{l}\text { Unulu bagian perairan dalam penetrasi buruk. } \\
\text { penghambar penetrasi sinar }\end{array}$ \\
\hline Muara sungai besar & - & $\begin{array}{l}\text { Tidak dijumpai sungai besar pada pulau, } \\
\text { tetapi beberapa muara sungai besar dari } \\
\text { daratan kalimantan sangat berpengaruh } \\
\text { terhadap perairan karang sekitar pulau. Hal } \\
\text { ini penyebab oscillasi salintas, kekeruhan, } \\
\text { alur polusi/sampah, \& eutrifikasi (peningkatan } \\
\text { unsur nutrisi). }\end{array}$ \\
\hline $\begin{array}{l}\text { Ledakan populasi Bintang Laut } \\
\text { (Acanthaster pranci) }\end{array}$ & - & $\begin{array}{l}\text { Tidak ada tanda pemuthan karang akibat } \\
\text { serangan bintang laut pemangsa karang. }\end{array}$ \\
\hline Lamun & + & $\begin{array}{l}\text { Tidak dijumpai adanya lamun di sekitar area } \\
\text { penelitian. Padahal lamun adalah suatu } \\
\text { ekosistem yang mendukung nutrien dan } \\
\text { penahan sedimen dan mempengaruhi (+) } \\
\text { keragaman ikan }\end{array}$ \\
\hline Mangrove & t異 & 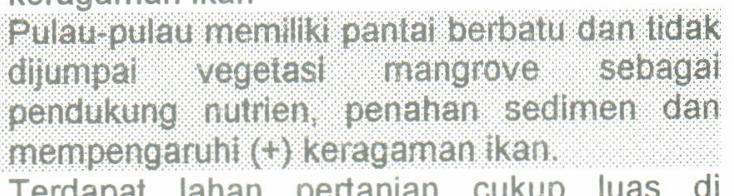 \\
\hline Aktivitas pertanian & - & $\begin{array}{l}\text { Terdapat lahan pertanian cukup luas di } \\
\text { beberapa wilayah Kalimantan Barat. } \\
\text { Penyebab eurifikasi pada badan air. }\end{array}$ \\
\hline Aktivitas pembangunan konstruksi & . & 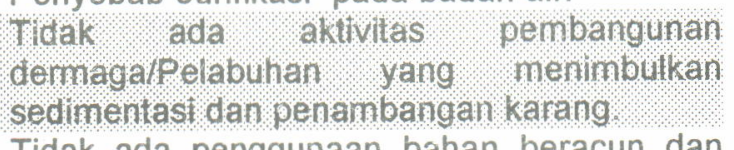 \\
\hline Aktivitas perikanan yang merusak & - & $\begin{array}{l}\text { Tidak ada penggunaan bahan beracun dan } \\
\text { peledak. }\end{array}$ \\
\hline Akivitas budi daya udang & ?. & $\begin{array}{l}\text { Pemanfaatan lahan mangrove yang cukup } \\
\text { tinggi. Penyebab hilangnya vegetasi. }\end{array}$ \\
\hline $\begin{array}{l}\text { Penggundulan lahan (land } \\
\text { clearing) }\end{array}$ & - & $\begin{array}{l}\text { Penggundulan vegetasi hutan dan mangrove. } \\
\text { Penyebab peningkatan sedimentasi. } \\
\text { Adanya peambangan e mas. fiar. penyebab }\end{array}$ \\
\hline Aktivitas pertambangan & mat & 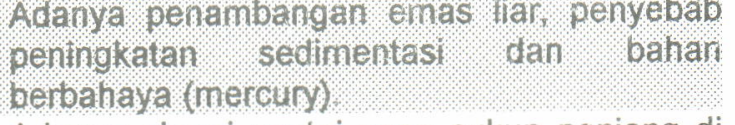 \\
\hline Abrasi pantai & - & $\begin{array}{l}\text { Adanya abrasi pantai yang cukup panjang di } \\
\text { Kalimantan Barat. Hal ini meningkatkan } \\
\text { sedimentasi yang memang sudah parah. }\end{array}$ \\
\hline
\end{tabular}

Keterangan: $(-)=$ berpengaruh negatif (negative impluence); $(+)=$ berpengaruh positif (positive influence $)$ 


\section{KESIMPULAN}

Beberapa hal yang dapat disimpulkan dari hasil penelitian ini antara lain adalah:

1. Kondisi kesehatan terumbu karang di stasiun 1, 2, dan 3 tergolong baik, sedangkan pada stasiun 4 (Pulau Kabung) tergolong sangat baik.

2. Tutupan karang keras (hard coral) pada stasiun 1, 2,3 , dan 4 masing-masing adalah $65,9 \% ; 65,37 \%$; $57,80 \%$; dan $78,9 \%$.

3. Sebaran spasial karang pada stasiun 1 dan 2 cukup rapat, sedangkan pada stasiun 3 dan 4 tidak rapat.

4. Sebaran karang dijumpai sampai dengan kedalaman 7 meter atau kurang lebih berjarak 100 meter dari garis pantai.

5. Jumlah marga karang tertinggi 16 genus dan terendah 13 genus.

6. Kekeruhan perairan yang tinggi merupakan pembatas bagi sebaran karang.

\section{SARAN}

Seyogyanya perencanaan pembangunan daerah yang memiliki sungai-sungai besar, seperti Kalimantan, mengganti model dari perencanaan yang berbasis kontinental menjadi berbasis kepulauan. Karena pulau-pulau kecil di sekitar pulau besar adalah bagian integral pulau besar yang menjadi induk di mana di antaranya terdapat sumber daya perairan atau ekosistem yang sangat potensial.

\section{DAFTAR PUSTAKA}

Anonimous. 2002. Pembangunan ekonomi maritim Indonesia. Brosur Dewan Maritim Indonesia, Jakarta.

Babcock, R. \& P. Davis. 1991. Effects of sedimentation on settlement of Acropora millepora. Coral Reefs 9:205-208.

Brown, B. E. \& L. S. Howard. 1985. Assessing the effects of stress on reef corals. Adv. Mar. Biol. 22:1-63.
Chou, L. M. 1998. Status of southeast asian coral reefs. In: status of coral reefs of the world: 1998. C. Wilkinson (Ed). Sida-Australian Institute of Marine Science-ICLARM Publising, Quensland, Australia.

Edrus, I. N. t. t. A study on coral reefs and coral fish in Watubela Islands, East Ceram, Moluccas. Internal Report for P3O-LIPI Ambon (Unpublished).

English, S., C. Wilkinson, \& V. Bakes. 1994. Survey manual for tropical marine resources. Australian Institute of Marine Science, Townsville. Australia.

Falkowski, P. G., P. L. Jokiel \& R. A. Kinzie III. 1990. Irradiance and corals. In: coral reefs: ecosystem of the world 25. Z. Dubinski (Ed.), Ellsevier, Amsterdam, Pp. 89-107.

Pontianak Post. 2004. Prihatin, daerah pesisir kian terkikis, Narasumber: Ir. Wawan HermawanKepala Bidang Pengawasan dan Pengendalian BAPEDALDA Kalimantan Barat, Harian Pontianak Post, Sabtu 19 Juni 2004.

Rahmat \& Yosephine. 2001. Software percent cover benthic lifeform versi 5.1. Pusat Penelitiaan dan Pengembangan Oseanologi LIPI, Jakarta.

Steffen, J. H. 2004. The role of remote sensing applications for integrated management of coastal and marine areas. Makalah Workshop Remote Sensing and GIS for Supporting Integrated Coastal Zone and Small Islands Management. BAKOSURTANAL, Cibinong, 22 Juli 2004.

White, A. T. 1987. Coral reefs: valuable resources of southeast asia. ICLARM Education Series 1, Manila, Philippines.

Wilkinson, C. R. \& R. W. Buddemeier. 1994. Global climate change and coral reefs: implications for people and reefs. Report of the UNEP-IOC-ASPEIIUCN Global Task Team on the Implication of Climate Change on Coral Reefs. IUCN Publications Service Unit, Cambridge, 124 pp.

Wilkinson, C. R, \& E. Evans. 1989. Sponge distribution across davies reef, great barrier reef, relative to location, depth and water movement. Coral Reefs 8: 1-7. 